\title{
The Effect of Leadership, Training, and Career Development on the Performance of the West Sumatra Police Personnel
}

\author{
Ariesna $^{1 *}$, Syamsul Amar ${ }^{2}$, Susi Evanita ${ }^{3}$ \\ 1,2,3 Universitas Negeri Padang, Padang, Indonesia \\ *Corresponding author.Email: ariesna35@yahoo.com
}

\begin{abstract}
This study examines the influence of leadership on training, career development, and the influence of leadership, training, and career development on performance. The number of respondents was 346 . The analysis technique used was path analysis to determine the influence of leadership, training, and career development on the performance of the West Sumatra Police personnel. The results of the study prove that: (1) Leadership has a significant effect on training; (2) Leadership has a significant effect on career development; (3) Training has no significant effect on career development; (4) Leadership has a significant effect on performance; (5) training has a significant effect on performance; (6) Career development has a significant effect on performance. The results of this study will have implications for the West Sumatra Police or other government organizations in improving performance through leadership, training, and appropriate career development. In addition, this study provides knowledge about the influence of leadership, training, and career development on performance.
\end{abstract}

Keywords: Leadership, Training career development, Performance.

\section{INTRODUCTION}

Talking about the performance of police personnel, indeed, it is inseparable from how police personnel behave on the job or outside their respective duties. Basically, work behaviour begins with the existence of education and training that forms knowledge and is accompanied by a positive work attitude, perceptions, values, and the abilities or competencies of police personnel. Without these aspects (of course those in the good category), it will be impossible to produce good performance in accordance with the goals and objectives of the job / task. However, due to various circumstances and demands as well as the influence of the environment and personality conditions that tend to be less strong, they have an adverse impact on daily life in the work environment and outside of work. Their behaviour will be different from their fellow police officers.

There are several factors that affect personnel performance. The results of previous research showed that career development has an effect on performance [1], [2]. Furthermore, personnel performance can also be affected by the training provided to personnel. Education and training have an effect on performance
[3]. Then, personnel performance can also be influenced by leadership. Research by Wang shows that leadership has an effect on performance [4]. Based on some of the opinions and results of previous research, it appears that the performance of personnel can be influenced by several factors examined in this study: career development, training, and leadership.

One of the factors affecting the performance of the West Sumatra Police personnel is leadership. There is an influence of leadership on performance [5], [6]. Furthermore, Iqbal's research shows that leadership such as democratic, autocratic, and participatory affects performance [7], which is in line with the results of Basit's study which shows democratic leadership and Laissez-faire have an effect on performance [8]. Meanwhile, the results of research conducted by Rathore show that transformational and transactional leadership affects performance [9].

Another factor that affects personnel performance is career development. Career according is all positions occupied by a person in his work life [10]. Career planning prepared by each individual clearly does not guarantee a successful career. Many factors support the 
success of a personnel's career development including high performance, adequate experience, high level of education, expertise and support from members and superiors. Matters related to the career development of member or personnel, namely work performance, exposure, networking, resignations, organizational loyalty, mentors and sponsors, key subordinates, growth opportunities, and experience [10].

Providing training in accordance with their fields will be able to produce good human resources who can support skills, knowledge, thoughts and insights so that they can be ready to work in accordance with their fields and have innovation, high creativity, analytical power and skilled at doing work. Leadership at the West Sumatra Police will also affect personnel performance. Effective leadership will make personnel carry out their duties and responsibilities optimally so that it will affect their career development and performance. Certainty in career development will also affect the performance of the West Sumatra Police personnel. Personnel who have a good career development will work optimally so that it will affect their performance.

Based on the background of the problems that have been discussed, this study will discuss "The Effect of Leadership, Training, and Career Development on the Performance of the West Sumatra Police Personnel."

\section{METHOD}

Based on the problems that will be discussed in this study, this type of research is a causality research. Sampling was 346 personnel. Sampling in this study using the proportional random sampling method, sampling of population members was carried out randomly and carried out by taking a percentage of the total population based on certain criteria in the population. The questionnaire was given to the West Sumatra Police personnel who had attended the training. This research uses path analysis as an analysis technique.

The research data collection instrument in the form of a questionnaire arranged according to research variables using a Likert scale, which is a method that measures attitudes by expressing the agreement of respondent or disagreement with a particular subject, object, or event. The following indicators are used in the questionnaire.

Table 1. Variable indicators

\begin{tabular}{|c|c|c|c|}
\hline No & Variable & $\begin{array}{c}\text { Operational } \\
\text { definition }\end{array}$ & Indicator \\
\hline 1 & Performance & $\begin{array}{l}\text { Performance is } \\
\text { the work } \\
\text { achieved by the } \\
\text { West Sumatra } \\
\text { Police personnel } \\
\text { in carrying out }\end{array}$ & 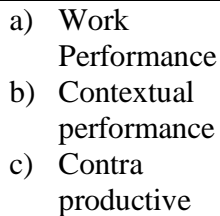 \\
\hline
\end{tabular}

\begin{tabular}{|c|c|c|c|}
\hline No & Variable & $\begin{array}{c}\text { Operational } \\
\text { definition }\end{array}$ & Indicator \\
\hline & & $\begin{array}{l}\text { the tasks and } \\
\text { responsibilities } \\
\text { assigned to } \\
\text { them. }\end{array}$ & behaviour \\
\hline 2 & Leadership & $\begin{array}{l}\text { Leadership is a } \\
\text { method used by } \\
\text { direct leaders or } \\
\text { superiors in } \\
\text { influencing } \\
\text { personnel to } \\
\text { achieve goals. }\end{array}$ & $\begin{array}{ll}\text { a) } & \text { Task Oriented } \\
\text { Leadership } \\
\text { b) } & \text { Relationship } \\
\text { Oriented } & \text { Leadership } \\
\text { c) } & \text { Change } \\
& \text { Oriented } \\
& \text { Leadership } \\
\text { d) Diversity- } & \text { Oriented } \\
& \text { Leadership } \\
\text { e) } & \text { Integrity } \\
& \text { Oriented } \\
& \text { Leadership }\end{array}$ \\
\hline 3 & Training & $\begin{array}{l}\text { Training is an } \\
\text { activity in } \\
\text { developing } \\
\text { personnel } \\
\text { capabilities by } \\
\text { providing access } \\
\text { and support to } \\
\text { personnel in } \\
\text { improving the } \\
\text { skills and } \\
\text { attitudes of the } \\
\text { West Sumatra } \\
\text { Police personnel. }\end{array}$ & $\begin{array}{l}\text { a) Motivation for } \\
\text { Training } \\
\text { b) Access to } \\
\text { training } \\
\text { c) Benefits } \\
\text { obtained } \\
\text { d) Support for } \\
\text { training. }\end{array}$ \\
\hline 4 & $\begin{array}{l}\text { Career } \\
\text { Development }\end{array}$ & $\begin{array}{l}\text { Career } \\
\text { development is a } \\
\text { process towards } \\
\text { a higher level of } \\
\text { position with the } \\
\text { career goals } \\
\text { desired by each } \\
\text { personnel being } \\
\text { achieved. }\end{array}$ & $\begin{array}{l}\text { a) Organizational } \\
\text { factors } \\
\text { b) Work and life } \\
\text { factors } \\
\text { c) Individual } \\
\text { career } \\
\text { management } \\
\text { strategies } \\
\text { d) } \\
\text { Career growth. }\end{array}$ \\
\hline
\end{tabular}

\section{RESULTS AND DISCUSSION}

\subsection{Normality Test}

The data normality test is carried out to test the assumption that the data distribution of the sample mean is close to population normality. The technique commonly used to perform the normality test is the Kolmogorov-Smirnov method. The results of the normality test show that the leadership variable (X1) has a significance value of 0.549 , this significance value is greater than the required alpha level $(0.05)$ or $0.649>$ 0.05 , it can be concluded that the leadership variable (X1) normally distributed.

Furthermore, the training variable (X2) has a normality significance value of 0.680 , this value is greater than the required alpha level $(0.05)$ or $0.680>$ 0.05 , thus, it can be concluded that the training variable (X2) is normally distributed. Career development 
variable (X3) with a normality significance value of 0.886 , this value is greater than the required alpha level $(0.05)$ or $0.886>0.05$. So, it can be said that the career development variable (X3) is normally distributed. The Performance variable (Y) has a normality significance value of 0.765 , this value is greater than the required alpha level $(0.05)$ or $0.765>0.05$, thus, it can be concluded that the Performance variable (Y) is normally distributed.

\subsection{Homogeneity Test}

After testing the normality of the data, the next step is the homogeneity test. The homogeneity test was carried out with the Levene test. This condition relates to the similarity of the variants of the endogenous variables for each exogenous variable group prices. From the results of the homogeneity test, it is known that the significance value of the homogeneity of each research variable is above 0.05 . The results of the homogeneity test showed that the respondents who were sampled in this study came from the same data group.

\subsection{Path Analysis}

The data analysis technique used in this study is the path analysis method, to explain the direct and indirect effects of a set of exogenous variables on endogenous variables. There are three sub-structures in this study: (1) leadership (X1) towards training (X2); (2) leadership (X1) and training (X2) towards career development (X3); (2) leadership (X1), training (X2), and career development (X3) on performance (Y). The first sub structure examines the influence of the leadership variable (X1) on training (X2).

Table 2. First sub-structure testing results

\begin{tabular}{|c|c|c|c|}
\hline Path & $\begin{array}{c}\text { Path } \\
\text { Coefficient }\end{array}$ & t-value & Sig. \\
\hline $\begin{array}{l}\text { Leadership on } \\
\text { Training }(\rho X 2 X 1)\end{array}$ & 0.561 & 12.566 & 0.000 \\
\hline \multicolumn{2}{|l|}{ R Square $\left(\mathrm{R}^{2}\right)=0.315$} \\
\hline
\end{tabular}

From the calculation of the first sub-structure path analysis, it can be seen that the coefficient of the leadership path to training $(\rho X 2 X 1)$ is 0.561 and the tcount is 12.566 at a significance value of 0.000 , which means that the path coefficient is significant. This means that leadership has a significant effect on training. Then, the calculation result of the influence of other variables on the influence of leadership on training was $68.5 \%$. This shows that there is a contribution of $68.5 \%$ which affects the training outside the variables studied (leadership).

Furthermore, the second sub structure examines the influence of the leadership variable (X1) and training (X2) on career development (X3). The following is the calculation result of the second sub-structure path analysis:
Table 3. Second sub-structure testing results

\begin{tabular}{|l|c|c|c|}
\hline \multicolumn{1}{|c|}{ Path } & $\begin{array}{c}\text { Path } \\
\text { Coefficient }\end{array}$ & t-count & Sig. \\
\hline $\begin{array}{l}\text { Leadership towards } \\
\text { career development } \\
(\rho X 3 X 1)\end{array}$ & 0.941 & 40.144 & 0.000 \\
\hline $\begin{array}{l}\text { Career } \\
\text { development } \\
\text { training }(\rho X 3 X 2)\end{array}$ & -0.013 & -0.557 & 0.578 \\
\hline \multicolumn{2}{|l|}{ R Square $\left(\mathrm{R}^{2}\right)=0.933$} & & \\
\hline
\end{tabular}

Based on these results, it shows that training has no significant effect on career development because it has a significance level above the required alpha (0.05), namely $0.578>0.05$. Because training does not have a significant effect, the path between training and career development is not included in the subsequent analysis (trimming).

After trimming without including the effect of training on career development, a re-analysis was carried out which examined the influence of leadership on career development so that the following results were obtained:

Table 4. Second sub-structure testing results (after trimming)

\begin{tabular}{|l|c|c|c|}
\hline \multicolumn{1}{|c|}{ Path } & $\begin{array}{c}\text { Path } \\
\text { Coefficient }\end{array}$ & t-value & Sig. \\
\hline $\begin{array}{l}\text { Leadership towards } \\
\text { career development } \\
(\rho X 3 X 1)\end{array}$ & 0.933 & 48.161 & 0.000 \\
\hline R Square $\left(\mathrm{R}^{2}\right)=0.871$ & & \\
\hline
\end{tabular}

Then, the calculation result of the influence of other variables on the influence of leadership on career development is $12.9 \%$. This shows that there is a contribution of $12.9 \%$ which affects career development outside the variables studied (leadership).

Furthermore, the third sub-structure examines the effect of leadership variables (X1), training (X2), and career development (X3) on performance (Y). The following is the result of the calculation of the third substructure of this research path analysis:

Table 5. Third sub-structure testing results

\begin{tabular}{|l|c|c|c|}
\hline \multicolumn{1}{|c|}{ Path } & $\begin{array}{c}\text { Path } \\
\text { Coefficient }\end{array}$ & t-count & Sig. \\
\hline $\begin{array}{l}\text { Leadership on } \\
\text { performance. } \\
(\rho \text { YX } 1)\end{array}$ & 0.140 & 2,753 & 0.006 \\
\hline $\begin{array}{l}\text { Performance } \\
\text { training. } \\
(\rho \text { YX2) }\end{array}$ & 0.486 & 22.706 & 0.000 \\
\hline $\begin{array}{l}\text { Career } \\
\text { development on } \\
\text { performance. } \\
(\rho \text { YX3 })\end{array}$ & 0.459 & 9.323 & 0.000 \\
\hline R Square $\left(\mathrm{R}^{2}\right)=0.893$ & & \\
\hline
\end{tabular}


Then, the percentage of total influence of leadership (X1), training (X2), and career development (X3) on performance $(\mathrm{Y})$ can be seen from the R2 value of 0.893. This means that leadership (X1), training (X2), and career development (X3) affect performance (Y) by $89.3 \%$.

The result of calculating the influence of other variables on performance is $10.7 \%$. This shows that there is a contribution of $10.7 \%$ which affects performance outside the variables studied (leadership, training, and career development).

\subsection{Discussion}

Leadership affects training. Leaders who are oriented towards increasing the knowledge and skills of their members will implement policies to increase the knowledge and skills, one of which is to provide training to their members. Leadership is one of the main factors in bringing positive change to an organization if there is no leadership in the organization, they will not be able to change in the direction they want and may experience negative changes instead. Leaders who send employees for further training will enhance their ability to do their job and help facilitate the effective implementation of the desired changes. In order to increase the level of knowledge and skills and to adapt to organizational changes, attention should be paid to training facilities and measures to increase the efficacy of training should be introduced [11]. Well-trained employees are able to control difficulties and difficult conditions and help improve the groups they work with, someone who is able to change the employee's behaviour is a leader [12].

The results of testing the second hypothesis indicate that leadership has a significant effect on career development at the West Sumatra Police. Leadership is an activity to influence the behaviour of others, or the art of influencing human behaviour, both individually and in groups. Good leadership can influence its members to work more effectively and to put more effort into their careers. It shows that leadership influences career development, one of which is employee promotion [13]. Furthermore, leadership tends to have an impact on women's career advancement in leadership roles [14]. Leadership has an effect on career development [15]. Based on some of the results of previous research and this opinion, it shows that leadership has an effect on career development. This study also analysed the influence of leadership in the West Sumatra Regional Police on the career development of the West Sumatra Regional Police personnel.

The results of testing the third hypothesis indicate that training has no significant effect on career development at the West Sumatra Police. Education and training are an effort to maintain, increase capacity, capacity and professionalism [16]. By providing training in accordance with their field of work it will affect their abilities. The results of this study are not in line with some research results which show that training has an effect on career development [17], [18]. Some of the reasons training does not have a significant effect on career development is because career development or career advancement of personnel will be achieved if the personnel have a working period suitable for career advancement, have a higher level of education and are relevant to the task as well as high work achievement.

The results of testing the fourth hypothesis indicate that leadership has a positive and significant effect on the performance of the West Sumatra Police personnel. Leadership is an individual's ability to influence, motivate, and make others able to contribute to the effectiveness and success of the organization [19]. Thus, successful leadership is one that can contribute to improving individual and organizational performance in general. The results of this study are in line with the results of research conducted which show that leadership has an effect on performance [4], [20].

The results of testing the fifth hypothesis indicate that training has a significant effect on the performance of the West Sumatra Police personnel. Education and training have an effect on performance [3], [21], [22]. Some of these opinions and studies show that training has an effect on performance. This study analyses the effect of the training given to the West Sumatra Police personnel on the performance of the West Sumatra Police personnel.

The results of testing the sixth hypothesis indicate that career development has a significant effect on the performance of the West Sumatra Police personnel. Career development programs are generally carried out with the aim of developing available talent more effectively, self-assessment opportunities for employees to think about traditional or new career paths, more efficient human resource development, satisfaction from employee personal development needs, performance improvement through on the job training experience, and a method of determining training and development needs. Career development has an effect on performance [1], [2], [23], [24].

\section{CONCLUSION}

Based on the results of the analysis relating to the objectives of this study, several conclusions can be drawn from the research results: Leadership has a significant effect on training at the West Sumatra Police. This means that the better the leadership, the more training will be given to the West Sumatra Regional Police. Leadership then has a significant effect on career development at the West Sumatra Police. This means that the better the leadership, the better career 
development at the West Sumatra Police. While training does not have a significant effect on career development at the West Sumatra Police. Leadership, training, and career development have a significant effect on the performance of the West Sumatra Police personnel. This means that the better the leadership, training, and career development, the higher the performance of the West Sumatra Police personnel.

\section{REFERENCES}

[1] S. Saleem and S. Amin, "The impact of organizational support for career development and supervisory support on employee performance: An empirical study from Pakistani Academic Sector," Eur. J. Bus. Manag., 5(5), pp. 194-207, 2013.

[2] A. M. Asfaw, M. D. Argaw, and L. Bayissa, "The impact of training and development on employee performance and effectiveness: A case study of District Five Administration Office, Bole Sub-City, Addis Ababa, Ethiopia," J. Hum. Resour. Sustain. Stud., 3(4), 2015.

[3] A. Elnaga and A. Imran, "The effect of training on employee performance,” Eur. J. Bus. Manag., 5(4), pp. 137-147, 2013.

[4] F.-J. Wang, S. Chich-Jen, and T. Mei-Ling, "Effect of leadership style on organizational performance as viewed from human resource management strategy," African J. Bus. Manag., 4(18), pp. 39243936, 2010.

[5] U. D. Mohammed, M. O. Yusuf, I. M. Sanni, T. N. Ifeyinwa, and A. O. Kazeem, "The relationship between leadership styles and employees' performance in organizations (A study of selected business organizations in Federal Capital Territory, Abuja Nigeria)," Eur. J. Bus. Manag., 6(22), 2014.

[6] N. Sunarsih and Helmiatin, "The influences of leadership style and job satisfaction on employee performance," J. Bus. Manag., 18(7), pp. 1-6, 2016.

[7] N. Iqbal, S. Anwar, and N. Haider, "Effect of leadership style on employee performance," Arab. J. Bus. Manag. Rev., 5(5), 2015.

[8] A. Basit, V. Sebastian, and Z. Hassan, "Impact of leadership style on employee performance (a case study on a Private Organization in Malaysia)," Int. J. Account. Bus. Manag., 5(2), pp. 112-130, 2017.

[9] K. Rathore, C. A. Khaliq, and N. Aslam, "The influence of leadership styles on employee's performance under perceptions of organizational politics: A study of Telecom Sector in Pakistan,"
Int. J. Manag. Res. Emerg., 7(1), pp. 106-140, 2017.

[10] V. Rivai and Sagala, Manajemen sumber daya manusia untuk perusahaan dari teori ke praktik. Jakarta: Rajawali Pers, 2011.

[11] S. S. Ikinci, "Organizational change: Importance of leadership style and training.," Manag. Organ. Stud., 1(2), pp. 122-128, 2014.

[12] A. Luthra and R. Dahiya, "Effective leadership is all about communicating effectively: Connecting leadership and communication," Int. J. Manag. Bus. Stud., 5(3), pp. 43-48, 2015.

[13] A. Priyabhashini and V. R. Krishnan, "Transformational leadership and follower's career advancement role of pygmalioneffec," Indian Journal lndustrial Relat., 40(4), pp. 482-499, 2005 .

[14] U. D. Jogulu and G. J. Wood, "The role of leadership theory in raising the profile of women in management," Equal Oppor. Int., 25(4), pp. 236250, 2006.

[15] H. A. Mukhtar, Efektivitas pimpinan: kepemimpinan transformatif dan komitmen organisasi. Deepublish, 2016.

[16] T. Ambar and R. Sulistiyani, Manajemen sumber daya manusia. Yogyakarta: Graha Ilmu, 2009.

[17] B. C. Charity, "Effect of training and career development on employee performance: A case of Kcb Branches in The North Rift Region, Kenya.," Int. J. Adv. Res. Manag. Soc. Sci., 4(5), pp. 38-49, 2015.

[18] H. Triharyanto, "Pengaruh pelatihan dan motivasi kerja terhadap pengembangan karir awak kapal pengawas perikanan pada Ditjen Pengawasan Sumber Daya Kelautan dan Perikanan (PSDKP)," J. Manaj. Perikan. dan Kelaut., 1(1), 2014.

[19] G. Yukl, M. O’Donnell, and T. Taber, "Influence of leader behaviors on the leader-member exchange relationship," J. Manag. Psychol., 2009.

[20] L. K. Kuria, G. S. Namusonge, and M. Iravo, "Effect of leadership on organizational performance in the health sector in Kenya," Int. J. Sci. Res. Publ., 6(7), pp. 658-663, 2016.

[21] B. R. Kotur and S. Anbazhagan, "Education and work experience influence on the performance," $J$. Bus. Manag., 15(5), pp. 104-110, 2014.

[22] M. P. Kowaas, "Pengaruh pendidikan, pelatihan dan disiplin kerja terhadap kinerja pegawai pada Badan Penanggulangan Bencana Daerah Provinsi Sulawesi Utara," Efisiensi, 16(3), 2016. 
[23] I. Azman, "The Effect of Job Satisfaction on Organizational Commitment," Manag. Mark., XIV (1), pp. 25-40, 2016, doi: 10.13140/RG.2.1.4082.3280.

[24] C. R. F. Worotitjan and J. Morassa, "Analisis perhitungan biaya produksi pada PT. Manado Nusantara Informasi (Koran Sindo)," J. EMBA J. Ris. Ekon. Manajemen, Bisnis dan Akunt., 4(1), 2016. 